Abstracta Iranica Abstracta Iranica

Revue bibliographique pour le domaine irano-aryen

Volume 27 | 2006

Comptes rendus des publications de 2004

« From 'Alien' to 'One of us': Field experiences in Iran ». Iranian Studies, vol. 37, n 4, (dec. 2004), pp. 603-612.

Jean-Pierre Digard

(2) OpenEdition

Journals

Édition électronique

URL : http://journals.openedition.org/abstractairanica/6703

DOI : 10.4000/abstractairanica.6703

ISSN : 1961-960X

Éditeur :

CNRS (UMR 7528 Mondes iraniens et indiens), Éditions de l'IFRI

Édition imprimée

Date de publication : 15 mai 2006

ISSN : 0240-8910

Référence électronique

Jean-Pierre Digard, « «From 'Alien' to 'One of us': Field experiences in Iran ». Iranian Studies, vol. 37, $n^{\circ} 4$, (dec. 2004), pp. 603-612. », Abstracta Iranica [En ligne], Volume 27 | 2006, document 382, mis en ligne le 02 janvier 2007, consulté le 25 septembre 2020. URL : http://journals.openedition.org/ abstractairanica/6703 ; DOI : https://doi.org/10.4000/abstractairanica.6703

Ce document a été généré automatiquement le 25 septembre 2020.

Tous droits réservés 


\title{
« From 'Alien' to 'One of us': Field experiences in Iran ». Iranian Studies, vol. 37, n 4, (dec. 2004), pp. 603-612.
}

\author{
Jean-Pierre Digard
}

Sur la base de diverses analyses d'expériences ethnographiques et de ses propres recherches depuis une quarantaine d'années dans le Lorestân, le Khorâsân et la région du golfe Persique, l'A., anthropologue iranienne vivant en Allemagne, analyse les difficultés de son positionnement sur le terrain vis-à-vis de ses informateurs locaux. L'expérience la plus cruciale voire douloureuse pour elle fut de découvrir que ceux-ci voyaient en elle, en tant que "native anthropologist", "mainly a source of potential assistance". Elle plaide pour qu'anthropologues étrangers et indigènes coopèrent davantage pour confronter leurs expériences. (Cf. c.r. n³78).

\section{INDEX}

Thèmes : 16.1. Iran

\section{AUTEURS}

JEAN-PIERRE DIGARD

CNRS - Paris 